\title{
The Impact of Microblog Culture and the Countermeasures for Ideological and Political Education in Colleges and Universities
}

\author{
Jing Chen \\ School of Nursing \\ Henan University \\ Kaifeng, Henan, China, 475004
}

\begin{abstract}
With the rapid development of information technology, microblog has been heavily promoted in the life of people. As a kind of new media, it has the characteristics of real-time, fissionability and diversity. At present, there are a large number of microblog users in the global range. No matter the enterprises, institutions, or the social celebrities and ordinary people are using microblog for getting or transferring information, and even national government also opens a microblog. Microblog is very popular and has received the consistent recognition and popularity in college and university students, which bring new opportunities and challenges for the ideological and political education management of colleges and universities in China.
\end{abstract}

Keywords-microblog culture; impact; the ideological and political education in colleges and universiiesy; countermeasure

\section{INTRODUCTION}

Microblog, this network media has been closely integrated into the life of the university students and become as a major means used by college students to link the world. Microblog culture not just has brought the huge impact to the campus cultural construction work, and also put forward higher requirements to the ideological and political education of college teaching, the education management face greater challenges. Therefore, universities should pay much attention to the microblog culture and construct it in the process of ideological and political teaching to facilitate the construction process of ideological and political education management work, and make its have effectiveness so that make it as a effective way constantly innovate and improve the teaching of ideological and political education. This paper mainly expounded the tremendous impact on the ideological and political education work in colleges and universities caused by microblog culture, and proposed the corresponding solution measures.
II. THE IMPACT OF THE IDEOLOGICAL AND POLITICAL EDUCATION WORK IN INSTITUTIONS OF HIGHER EDUCATION CAUSED BY THE INFILTRATION OF MiCROBLOG CULTURE

\section{A. The Idea Innovation to the Ideological and Political Education Work}

People's cognition and thought constantly change with the rapid development of The Times .The popularization of information technology not only cause great impact to the people life style, work style and learning style but also greatly impact the people's values, outlook on life and world view. College students have great curiosity, constantly contact new things and have strong acceptation ability. Microblog culture has the most impact and temptation to them. With the popularity of microblog culture, the value orientation and ideas of college students will be greatly affected, and it is inevitable to produce new change, which also put forward higher requirements to the ideological and political education of college work. The traditional ideological and political education take the teacher unilateral teaching as the principle of work and unify the student thought through the theory learning. In the education teaching process, take the students as the modification objects, do not pay enough attention to the individual demands and characteristics of students or do not embody the specific embodiment of the principle status of students, the education teaching means does not have flexibility which make the ideological and political education work can not play a good effective guidance in the process of students' life and learning as expected.

\section{B. The Channel Development to the Ideological and Political Education Work}

Generally, the traditional teaching is adopted in carrying out ideological and political education work in colleges and universities, which is dominated by the school to expound the lecture to students mechanically. This way and the means used by teachers has taken serious lag in the teaching process , which is not tally with the demand of the Times and make the students think the classroom teaching is old and rigid and lose interest in learning, then the ideological and 
political education work cannot play its role in guiding. At present, the characteristics of pursuit of appeal and the individuality expression of university student is being embodied fully at large and form an independent individual. Therefore, it has a strong resistance to the dogmatic and formal means and ways used in education teaching in colleges and universities. If the university leaders fail to understand and accurately grasp the students' demand, value orientation and ideology, it will bring serious consequences that the ideological and political education work way do not tally with the demand for the development of students and the teaching direction.

\section{Timely Grasp of the Ideological and Political Education Work}

As a communication platform, microblog is relatively open and can provide people with a loose and free social environment, can help people realize the equality of barrierfree communication. In microblog, students need not scruple the identity of the teachers, can fully express their own ideas and value orientation, which can enlarge the interpersonal level of students, improve the students' ability of language expression and cultivate the students' independent thinking, so as to promote individual socialization process. If the ideological and political education work of colleges and universities want to achieve good results, it will be the first and foremost condition that fully understand the student, grasp the students' ideology and ideological confusion, carry on the ideological and political education with directed attention, help students solve doubts and set up the correct ideological and political idea. While microblog is the important medium for students to convey the thoughts, student's ideas are embodied in the microblog have strong representation and reality. Therefore, the leadership of colleges and universities should actively and reasonably use microblog in the process of carrying out ideological and political education work to effectively improve education teaching effect.

\section{The Potential Risks to Ideological and Political Education Work}

With the deepening popularity degree of microblog, the communication between students, teachers and leaders of colleges and universities is more and more simple and direct. Although microblog has a role in promoting in culture construction in colleges and universities, it also brings potential risks to the ideological and political education work .If there is a social hot spot, the college students will bubble up on it and a lot of rumors and false information will be on spread rapidly via microblog, which is easy to cause bad social influence and also indirectly impact the cost control work to colleges and universities and make them have no choice but add the teaching cost. Microblog do not strictly regulate the moral bottom line and forbid the language violence, so it is easy to appear vulgar information at microblog platform which has a serious misleading on university student's thought, and even induce college students to the path of crime. Due to the potential risk of harm and negative effect caused by popular microblog, university leaders need to carry out targeted ideological and political education work to guide the ideological concept and value orientation of college students.

\section{THE EFFECTIVE COUNTERMEASURES OF THE} IDEOLOGICAL AND POLITICAL WORK IN COLLEGES AND UNIVERSITIES TO THE IMPACT OF MICROBLOG CULTURE

\section{A. Form A Correct View of Cognition on the Role of Microblog}

Continuous innovation and improvement of science and technology promote the development of the microblog industry, at present, microblog has become the main means of information dissemination for people, especially for the college students, who highly recognize and pursuit it, which has caused crucial effect to the ideological and political education in colleges and universities. Therefore, leaders of colleges and universities should pay much attention to microblog, reasonably use microblog in the process of carrying out ideological and political education work to stimulate students' interest in learning and help them set up correct concept and value orientation.

First of all, the leaders need to have a clear orientation to the using value of microblog, clear the promoting function of microblog to the ideological and political education in the face of microblog influence, and can not blindly cater to the needs of students and exaggerate the function of the microblog. Microblog can be used to carry out the ideological and political education work smoothly only in this way. Second, the leaders of colleges and universities not only adopt microblog to improve the ideological and political education work, but also integrate it into the carrier of the traditional education teaching as a medium to make the teaching carrier play a more important role via this cooperation style. Finally, in the face of public opinion of microblog, university leaders should undertake correct teaching to the student, help them form good literacy of microblog media, which not only can help students achieve self-discipline and rationally treat the microblog information, but also can brings its own effectiveness of ideological and political education.

\section{B. Construct the Ideological and Political Education Platform via Microblog}

With the speeding up of the information age, microblog has become the main medium of information dissemination for people and has been widely promoted in various fields. Facing the trend of social development, as advanced talent training base of our country, the colleges and universities should conform to the trend of the Times to open the microblog official platform and take it as a communication bridge to promote the communication of students and teachers. At present, microblog with special topic in our country is few, universities should tightly catch the opportunity and open microblog in view of the ideological and political education to help the student fully recognize the importance of ideological and political education, so as to guide students to form correct ideas. 
The leaders of colleges and universities should provide specialized personnel responsible for the official microblog platform to encourage the ideological and political education in universities have effectiveness. The responsible person can be chosen from information technology professionals, the staff of propaganda department of the school or the workers of ideological and political education. In addition, the duty of the responsible personnel should be cleared, for example, reply comments, write content and search the related information etc. If the leaders of colleges and universities want to realize the modernization of the official platform, the platform content should cover the world outlook, the aesthetic and moral values, etc.. The relevant staff should undertake the student survey to select the microblog form, which should be made, based on the students' preferences for establishment, for example, audio, video, images, etc.. It can bring the vitality and the interest to microblog to gain more followers. The staff should update microblog content, reply comment from the student in detail, accurately and patiently answer students doubts, as that fully play the function of microblog as an official platform.

\section{Integrate Microblog into the Carrier of Ideological and Political Education}

The efficiency of ideological and political education work and education quality of teaching can be multi-angle and all-round improved only by blending microblog into traditional ideological and political education teaching carrier to form education resultant force. The carrier of activities, for example, as a traditional carrier, colleges and universities mainly conduct some ideological and political education activities via it, and help students form a correct concept of ideological and political in the activities, volunteer activity is one of the representatives. Integrate microblog into the activity carrier, the related responsible staff can use microblog to promote activities in the early period, record the entire activities, then select photos matching the corresponding text with activity characteristics, put them on the microblog for students to browse, which not only can improve the sense of accomplishment of volunteers, set a good example for other students, also can attract more attention, effectively promote the job of teaching of ideological and political education process, prompt the work of ideological and political education of college teaching to achieve high efficiency and high quality and finally achieve good results.

\section{Establish and Perfect the Running Security System in View of the Microblog Platform}

To fully play microblog function in the process of carrying out ideological and political education teaching work in colleges and universities, it is necessary to constantly purify microblog environment, establish and perfect the guarantee system and ensure that microblog can be run safely. First of all, universities should develop a series of standards according to the microblog official platform to strengthen the management of microblog level, and audit strictly the information released by it; Second, implement identity authentication system to microblog followers, for example, real-name authentication measures taken by sina microblog, to ensure safety in the process of using microblog; Finally, universities should build a supervision and management system to supervise the entire process of microblog, regularly sort and filter the internal microblog group in campus and clear the garbage information in time, for example, rumors, error messages, etc., to ensure that the information accurate of microblog platform, though which to create a good environment for the microblog for students and promote the process of ideological and political education of college teaching work.

\section{CONCLUSION}

In a sense, microblog culture not only is a kind of information transmission media, reasonably using microblog can help people to shape concept structure and thought. Extensive use of microblog has brought new challenge to the ideological work in colleges and universities, meanwhile, it also offers a new way, idea and visual angle for ideological work in colleges and universities, which prompt constant innovation and improvement in the process of the ideological education, it conforms to the demand of the social development and train talents with good ideological and political quality for the society.

\section{REFERENCES}

[1] Yanqiu Xu. The Impact of Microblog Culture and Countermeasures of Ioeological and Political Education from College and University [J].Front, 2013 (16).

[2] Hongming Guo, Yongcan Wang. Interactive Mode of Ioeological and Political Education in College and University on Basis of Microblog [J].Education Management of College and University,2013(06).

[3] Guowei Gao, Guanghua Zhang, Analysis of Teachers' Media Literacy Education of Ideological and Political Theory Course in Microblog Environment [J].Theory Monthly,2013 (04)

[4] Zhongliang Sun, Cuihua Lu. The Influence and Countermeasures to the Ideological and Political Education Management in College and University of Microblog Culture [J]. Modern Education Management, 2013 (7).

[5] Qiongzhong Wu. The Conflict and Fusion to the Ideological and Political Education in College and University of Microblog culture [J]. Journal of Jilin Institute of Education (middle), 2015 (05).

[6] Yi Li. Research on Conflict and Countermeasures to the Ideological and Political Education in College and University of Microblog [J]. Journal of Mudanjiang Education College, 2015 (04).

[7] Ying Liao . The Challenge and Countermeasures to the Ideological and Political Education in College and University of Microblog [J]. Journal of Theory, 2011 (16).

[8] Yanning Cao. New Path to Microblog and Ideological and Political Education in College and University [J]. Journal of Changshu Institute of Technology, 2012 (11). 